\title{
TiBuana
}

\section{INVENTORY CONTROL PLANNING CRAFTS OF PEARL LEATHER SKIN IN THE CITY OF AMBON USING THE AGGREGATE METHOD}

\author{
Marcy L. Pattiapon \\ Industrial Engineering Department, Faculty of Engineering, Pattimura University, Ambon \\ Email : marcylolita_unpatti@yahoo.com
}

\begin{abstract}
Maluku is an archipelago that is rich in natural products, especially the sea including pearl shells. One small industry that is quite developed in the city of Ambon is the handicraft industry made from pearl shells. pearl shells are utilized and treated as crafts with high artistic value is one of the characteristics of the Maluku region which is one of the souvenir choices that is quite attractive to domestic and foreign tourists. Besides being consumed, shellfish also produce pearls and are often made into jewelry such as necklaces, bracelets, rings and wall hangings and various accessories. Fluctuations in demand from time to time cause the need for inventory planning by forecasting the needs of the future. Forecasting used is the Time Series Moving Average and Single Exponential Smoothing.Based on the results of research conducted can be seen that the biggest capital absorbers are pearl shells, profiles, velvet cloth and glass. Forecasting with Moving Average $(M A)=4$ months has the smallest error value with forecast results is $57 \mathrm{~kg}$. With a total cost of $R p$. 5,156,847,779. The alternatives used in aggregate planning are a strategy with regular regular working days and an overtime strategy, which is 26 days / month, with a production capacity of 39 units of finished shell products. With a total cost of Rp. 243,650,000.
\end{abstract}

Keywords: $A B C$ Classification, Inventory Control, Forecasting, Aggregate.

\section{INTODUCTION}

Maluku is an archipelago that is rich in natural products, especially the sea including pearls. One alternative to reduce exploitation of natural resources in Maluku is to utilize shellfish waste as raw material for making shellfish crafts. Several studies on shell-based waste products have been conducted in several places in Indonesia (Design development has also been carried out (Hariyadi, Asyiah, \&Fatahillah, 2013; Hastuti, Arifin, \&Subagya, 2011; Sari, Rismana, Suseno, Tyas, \&Lailassalami , 2013) However, it is usually done in coastal cities and still uses handmade and traditional approaches.

One of the small industries that is quite developed is the handicraft industry made from pearl oyster shell, pearl oyster shell and is used as a craft with high artistic value. and abroad. Pearl mussels are soft-bodied marine organisms or mollusks that live at sea, their bodies are protected by a pair of thin and hard shells. Besides being consumed, shellfish also produce pearls and are often made into jewelry such as necklaces, bracelets, rings and wall hangings and various accessories. BatuMerah Village is a place of business for pearl oyster leather craftsmen who at the same time market the products produced, in the procurement of raw materials, still in the traditional way or based on estimates. The types of products produced from pearl shells are quite diverse with interesting motives including wild horse motifs, calligraphy and getshsemane. At present there are around 16 business units but 9 craftsmen are included.

The problem that is suspected to occur is that so far the craftsmen have controlled the supply of raw materials for pearl oyster crafts based only on simple experience and understanding. Fluctuations in demand from time to time require that the planning of raw material inventories be carried out to meet the needs of future production, but still pay attention to the inventory costs to be incurred by craftsmen.

To achieve these objectives it is necessary to do inventory planning with attention to the level of importance of the goods that can be viewed from the level of criticality of the goods, the speed of use or the level of profit that can be achieved and based on the level of capital absorption. 


\section{TiBuana}

\section{Journal of applied Industrial Engineering-University of PGRI Adi Buana}

p-ISSN 2622-2027

$e$-ISSN 2622-2035

\subsection{Pearl Shell}

\section{METODS}

Pearl oysters are soft-bodied, non-vertebrate marine animals protected by two asymmetrical, thick and very hard shells (Sutaman, 1993). Pearls are one of the commodities of the marine sector with high economic value and have business development prospects in the future. This can be seen from the increasing number of enthusiasts in pearl jewelry and the price that has increased from year to year. The potential of pearls from Indonesia which are traded in the world market has the potential to be increased. Efforts to obtain pearls are currently experiencing development, originally obtained from the results of sea diving, now it has been done in the form of cultivation.

In addition to traded pearls, pearl shells can also be used to be processed into jewelry, accessories and others. Pearl shells (Pinctada maxima) are covered by a pair of oyster shells (Shell) that are not of the same shape. The right skin is slightly flat, while the left skin is slightly convex. Species have dorsal-ventral and anterior-posterior diameters about the same so that they are rather round in shape. Dorsal part of a long flat shape like a black hinge that functions to open and close the shell. The shell is composed of lime which is released by the outer ephitel. These outer ephithelial cells also produce calcium carbonate crystals $(\mathrm{Ca} \mathrm{CO} 3)$ in the form of argonitycrystals which are better known as nacre and hexagonal calcite crystals which form layers of prisms such as the shell.

\subsection{Definition of Forecasting}

Forecasting is an estimate of the level of demand expected for a product or several products in a certain period of time in the future. Forecasting is not really needed in the demand for stable market conditions, because changes in demand are relatively small, but demand forecasting will be needed if market demand conditions are complex and dynamic.

The main purpose of demand forecasting is to predict the demand for independent demand items (demand for materials, products not directly related to the bill of material structure) in the future.

\subsection{Time Series Forecasting Methods}

The time series forecasting methods are as follows:

\section{a. Moving Average}

Moving averages are obtained by averaging requests based on some recent past data. The purpose of the MA method is to reduce or eliminate random variations in requests. Mathematically, the MA is stated as follows:

$$
\text { Moving average } \mathrm{n}-\text { periods }=\frac{\sum(\text { Demand in the previous period } \mathrm{n})}{n}
$$

\section{b. Exponential Smoothing}

The exponential smoothing forecasting model is based on the following formula:

$$
F_{\mathrm{L}}=F_{\mathrm{I}-1}+u\left(A_{[-1}-F_{\mathrm{I}-1}\right)
$$

\subsection{Inventory Definition}

Inventories are idle resources awaiting further processing (Nasution, 1999). Inventories can also be interpreted as materials stored in warehouses for later use or sale. Inventories can be in the form of raw materials for processing, goods that are still in processing and finished goods that are stored for sale.

\subsection{Inventory Model}

\section{a. EOQ (Economic Order Quantity) Method}

This EOQ (Economic order Quantity) model is used to determine how many raw materials or products must be ordered to minimize inventory storage costs. Inventory has a purpose so that companies can buy or make items in economical quantities. EOQ is the number of orders that can minimize total inventory. The EOQ formula is as follows:

$$
Q^{*}=\sqrt{\frac{2 C . R}{H}}=\sqrt{\frac{2 C . R}{P . F}}
$$

TiBuana, Vol.03, No. 2, 2020|73 
Total Inventory Cost :

If at a certain period, there is a shortage of inventory, the shortage of raw material for semolina flour will be fulfilled in the future (backorder). The cost component included in the backorder case here is the cost that must be incurred due to the production process delay. So it will cause losses. In the backorder condition in this case, it is assumed that all shortages of raw material for pearl oyster shells will be fulfilled on the next order shipment. By INASEA, Vol. 6 No. 124 2, October 2005: 109-133 because of this, often the number of items that are backed up in a negative condition means that the amount must be met in the future to meet the deficiencies that occur. Following is the formula used for:

1. Determine the economical order quantity $(\mathrm{Q}$

*)

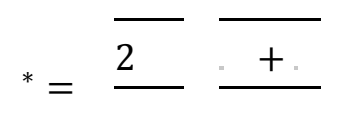

2. Maximum number of backorder $(\mathrm{J} *)$

3. Reorder point (B)

$$
J^{*}=\frac{H^{*}}{H+K}
$$

$$
B=\frac{K}{N}-J^{*}
$$

\subsection{Aggregate Planning}

Aggregate production planning departs from the problem of an imbalance between demand and production capability at each planning period. This is because in general the level of demand for a product is always not the same from one period to another period. Sometimes the level of demand is above production capacity, and sometimes below the level of production capacity. The purpose of aggregate production planning is to develop a production plan at an appropriate aggregate level to achieve a balance between demand and product capacity with minimum costs(Bedworth, 1987).

\section{RESULTS AND DISCUSSION}

\subsection{Demand for Shells}

The following table 1 below is a data table of requests for pearl oyster shell crafts in the BatuMerah village of Ambon from June 2016 to May 2019.

Table 1. Demand Shell Data in Batu Merah Village

\begin{tabular}{lcc}
\hline \multicolumn{1}{c}{ Period } & Time period & Data \\
\hline June '16 & 1 & 65 \\
July & 2 & 40 \\
August & 3 & 70 \\
September & 4 & 45 \\
October & 5 & 60 \\
November & 6 & 78 \\
Desember & 7 & 55 \\
January '17 & 8 & 63 \\
February & 9 & 47 \\
March & 10 & 59 \\
April & 11 & 67 \\
May & 12 & 75 \\
June & 13 & 46 \\
July & 14 & 50 \\
August & 15 & 72 \\
September & 16 & 48 \\
October & 17 & 57 \\
November & 18 & 63 \\
\hline
\end{tabular}




\section{TiBuana}

Journal of applied Industrial Engineering-University of PGRI Adi Buana

$p$-ISSN 2622-2027

$e$-ISSN 2622-2035

\begin{tabular}{llc}
\hline Desember & 19 & 49 \\
January '18 & 20 & 50 \\
February & 21 & 67 \\
March & 22 & 78 \\
April & 23 & 65 \\
May & 24 & 167 \\
June & 25 & 200 \\
July & 26 & 74 \\
August & 27 & 48 \\
September & 28 & 156 \\
October & 29 & 176 \\
November & 30 & 64 \\
Desember & 31 & 79 \\
January ' 19 & 32 & 56 \\
February & 33 & 78 \\
March & 34 & 49 \\
April & 35 & 59 \\
May & 36 & 42 \\
\hline
\end{tabular}

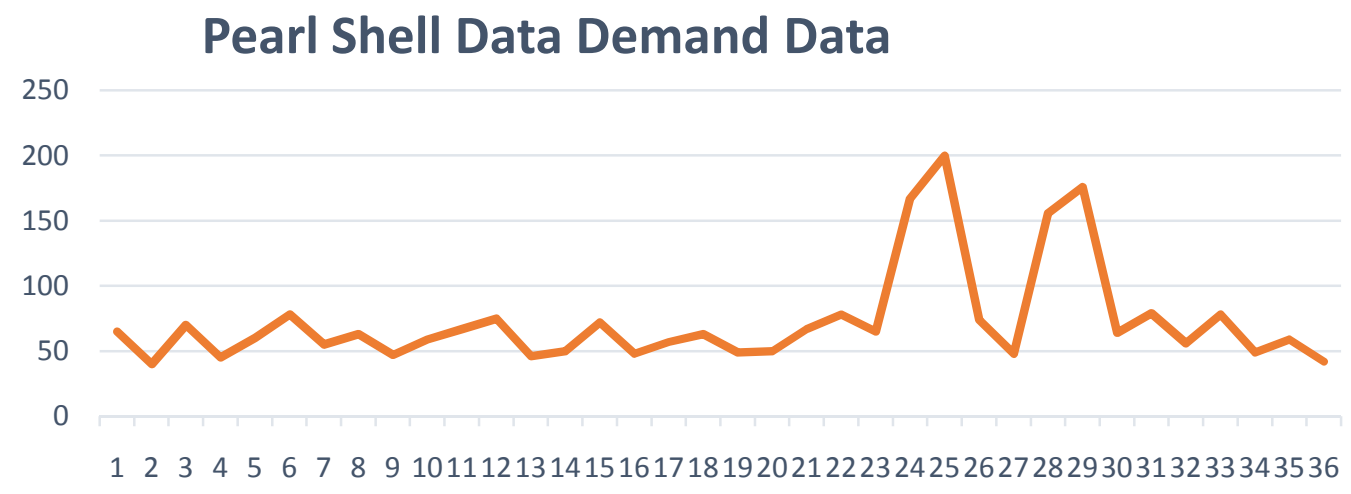

Figure 1. Graph of Pearl Shell Skin RawMaterial Demand

The results of the error analysis can be seen in table 2.

Table 2. Error Analysis

\begin{tabular}{ccccccc}
\hline & \multicolumn{7}{c}{ Error Analysis } \\
& F1 & F2 & F3 & F4 & F5 & F6 \\
\hline MAD & 26.14 & 27.15 & 28.55 & 27.38 & 27.53 & 27.79 \\
MAPE & 33.95 & 34.94 & 36.42 & 37.36 & 37.94 & 38.52 \\
MSE & 1445.51 & 1546.02 & 1702.53 & 1654.07 & 1711.82 & 1738.76 \\
\hline
\end{tabular}

Based on the data request for the main raw material, namely pearl shells over a 36 month period in which the demand data processing is used two forecasting methods as a comparison. The two methods are the Single Moving Average method and the Single Exponential
Smoothing method. The Single Moving Average (MA) method used is MA (4), MA (5) and MA (6). While the Single Exponential Smoothing method uses $\alpha=0.8, \alpha=0.9$ and $\alpha=0.95$. Based on the analysis of the errors used, the 
smallest forecasting error is found in the 4-

\subsection{Inventory Model}

a. Raw Material Inventory Model With EOQ

1. The forecast result of the Moving Average (4) forecast is $57 \mathrm{~kg}$

2. Order amount each time: $29.387 k$

3. Number of orders in one year $(\mathrm{m}): 61.47$ $\sim 61$ times / year

4. Order Interval $(\mathrm{T}): 4.69$ days $\approx 5$ days

5. Total Cost (TC) : 5.156.847.779

Based on the calculation above, the planning time period is $57 \mathrm{~kg}$ of pearl shells. From the above number of requests, the number of economic orders for pearl oysters that the company can make is $29,367 \mathrm{~kg}$ of pearl oysters. So it can be said that in one planning year, the company ordered $29,367 \mathrm{~kg}$ of seashells every 5 days or 61 times in one year.

b. Inventory Model With Backorder

1. Economical Order Amount $(\mathrm{Q} *)=$ $398.69 \mathrm{Kg}$

2. Maximum number of backorder $(\mathrm{J} *)=$ 350.85 month Moving Average method or MA (4).

3. Reorder point $(\mathrm{B})=-350.85$

4. Longest waiting time (Longest Delay Time $)=4.38$ days $\sim 5$ days

5. Total cost $(\mathrm{TC})=51.052 .650$

From the above calculation it can be concluded that the economic order has increased from $29,387 \mathrm{~kg}$ to $398.69 \mathrm{~kg}$ of seashells. When the company adopts a backorder policy, costs fall to the total cost of the order as much as Rp. 5,156,847,779 - Rp. $51,052,650=$ Rp. $5,105,795,129$. With the same waiting time of 5 days.

\subsection{Calculation of Distribution Model From Aggregate Planning}

\section{Forecast Demand for Scallop Handicraft Products}

To find out the level of production or capacity per period, the following table is made:

Table 3. Production Requirements and Cost and Inventory Data for Finished Products of Pearl Shells

\begin{tabular}{lccccc}
\hline \multicolumn{1}{c}{ Year } & Period & Day of Period & $\begin{array}{c}\text { Requirement } \\
\text { (Unit) }\end{array}$ & $\begin{array}{c}\text { Max. Per Period } \\
\text { Regular } \\
\text { hours(Unit) }\end{array}$ & $\begin{array}{c}\text { Overtime } \\
\text { hours(Unit) }\end{array}$ \\
\hline June 2019 & 37 & 26 & 39 & 312 & 130 \\
July & 38 & 27 & 39 & 324 & 135 \\
August & 39 & 26 & 39 & 312 & 130 \\
Sepetember & 40 & 26 & 39 & 312 & 130 \\
Oktober & 41 & 26 & 39 & 312 & 130 \\
Nopember & 42 & 26 & 39 & 312 & 130 \\
Desember & 43 & 24 & 39 & 288 & 120 \\
January & 44 & 26 & 39 & 312 & 130 \\
Februari & 45 & 24 & 39 & 288 & 120 \\
March & 46 & 27 & 39 & 324 & 135 \\
April & 47 & 25 & 39 & 300 & 125 \\
May 2020 & 48 & 27 & 39 & 324 & 135 \\
\hline
\end{tabular}

After calculating using the transportation model using data obtained from the company, we obtain:
Total Cost of Rp.243,650,000, - by producing the following: 
Table 4. Production Plan for Pearl Shellfish Finished Products

\begin{tabular}{cccc}
\hline Period & Demand & $\begin{array}{c}\text { Production Plan } \\
\text { (Unit) }\end{array}$ & $\begin{array}{c}\text { Production } \\
\text { (Unit) }\end{array}$ \\
\hline 1 & 39 & 14 & 14 \\
2 & 39 & 39 & 39 \\
3 & 39 & 39 & 39 \\
4 & 39 & 39 & 39 \\
5 & 39 & 39 & 39 \\
6 & 39 & 39 & 39 \\
7 & 39 & 39 & 39 \\
8 & 39 & 39 & 39 \\
9 & 39 & 39 & 39 \\
10 & 39 & 39 & 39 \\
11 & 39 & 39 & 39 \\
12 & 39 & 39 & 39 \\
\hline
\end{tabular}

\section{CONCLUSION}

The conclusions obtained are as follows:

1. Production Planning and Control

a. The forecasting method used to determine the prediction of the main raw material for pearl oyster shells for the coming period is the Moving Average method (4 months). Forecasting results for the coming period amounted to $57 \mathrm{~kg}$ of raw material for pearl oysters.

b. The number of economical orders is $29 \mathrm{~kg}$ ordered 61 times a year with order intervals every 5 days. While the total cost of inventory issued is $\mathrm{Rp}$. $5,156,847,779$.

\section{BIBLIOGRAPHY}

1. Bedworth, D.D. and J.E. Bailey. 1987. Integrated Production Control Systems: Management, Analysys, Design. Second Edition. New York: John Wiley and Sons.

2. Gaspersz, V. 2004, Production Planning And Control. PT. Gramedia Pustaka Utama, Jakarta.

3. Handout Perencanaan dan Pengendalian Produksi, ITB, Bandung, 2004.

4. Hariyadi, S., Asyiah, I. N., \&Fatahillah, A. 2013. Pelatihan desain kerajinan kerang pada pengrajin kerang di Kabupaten Situbondo. Jember: Universitas Jember, Tidak Diterbitkan.

5. Hastuti, L. S. S., Arifin, A., \& Subagya. 2011. Pengembangan Desain Produk Seni
2. Aggregate Planning

a. The forecasting method for determining the forecast of raw material for shells 1 for the coming period is the moving average method (4). The forecast result for 1 year is 39 units.

b. The alternatives used in aggregate planning are a strategy with regular regular working days and an overtime strategy, which is 26 days / month, with a production capacity of 39 units of finished shell products. With a total cost of Rp. 243,650,000

Kerajinan Kerang Simping. Dinamika Kerajinan Dan Batik, 29 (Juni), 37-42.

6. Makridakis, S.dan Wheelwright S C., 1991, Metode dan Aplikasi Peramalan Jilid 1, Jakarta: Erlangga.

7. Nasution, A. H. (1999), Perencanaan dan Pengendalian Produksi. Guna Widya, Jakarta.

8. Sari, E. D. T., Rismana, A. D., Suseno, Tyas, C. A., \& Lailassalami, U. 2013. Program Kreativitas Mahasiswa Pemanfaatan Kerang Laut untuk Usaha Souvenir. Semarang: Fakultas Ilmu Komputer, Universitas Dian Nuswatoro, Tidak diterbitkan.

9. Sutaman. 1993. Tiram Mutiara: Tehnik Budidaya dan Proses Pembuatan Mutiara. Penerbit Kanisius. Yogyakarta: 93 hal. 